\title{
The effects of a diet formulation with oats, soybeans, and flax on lipid profiles and uricemia in patients with AIDS and dyslipidemia
}

\author{
Rosângela dos Santos Ferreira ${ }^{[1],[2], ~ D a i a n e ~ C o l m a n ~ C a s s a r o ~}{ }^{[3]}$, \\ Hamilton Domingos ${ }^{[4]}$, Elenir Rose Jardim Cury Pontes ${ }^{[5]}$, Priscila Hiane Aiko ${ }^{[5]}$ \\ and Júnia Elisa Carvalho de Meira ${ }^{[2],[6]}$
}

[1]. Programa de Pós-Graduação em Saúde e Desenvolvimento na Região Centro-Oeste, Universidade Federal do Mato Grosso do Sul, Campo Grande, MS. [2]. Serviço de Nutrição, Hospital das Clínicas, Universidade Federal do Mato Grosso do Sul, Campo Grande, MS. [3]. Residência em Clínica Médica, Faculdade de Medicina de São José do Rio Preto, São José do Rio Preto, SP. [4]. Departamento de Clínica Médica, Faculdade de Medicina, Universidade Federal do Mato Grosso do Sul, Campo Grande, MS. [5]. Centro de Ciências Biológicas e da Saúde, Departamento de Tecnologia de Alimentos e Saúde Pública, Universidade Federal do Mato Grosso do Sul, Campo Grande, MS. [6]. Programa de Pós-Graduação em Bioquímica, Instituto de Nutrição Josué de Castro, Universidade Federal do Rio de Janeiro, Rio de Janeiro, RJ.

\begin{abstract}
Introduction: Although the initiation of highly active antiretroviral therapy (HAART) is accompanied by an attenuation of viral load, metabolic disorders characterized by hyperglycemia, dyslipidemia, and lipodystrophy are often observed in patients under this treatment. Certain foods, such as oat bran, soy protein, and flaxseed, have been shown to improve a patient's lipid profile despite possible increases in uricemia. Thus, a bioactive compound was formulated using these foods to help patients with HIV/ AIDS control metabolic disorders resulting from HAART. Methods: An uncontrolled before and after study was performed. The total cholesterol, HDL-cholesterol, LDL-cholesterol, triglycerides, and uric acid before and after 3 months of consuming the formulation were compared in patients. The compound was formulated such that $40 \mathrm{~g}$ (the recommended daily intake) contained approximately $10 \mathrm{~g}$ of flaxseed, $20 \mathrm{~g}$ of oat bran, and $10 \mathrm{~g}$ of textured soy protein. Results: The study population consisted of 139 patients, 31 of whom were included in the final analysis. There were no significant variations between the laboratory results obtained before and after consumption of the compound. Conclusions: The regular consumption of the formulation together with individualized dietary guidance did not reduce lipid levels and did not contribute to an increase in uricemia in the study group. However, new studies with higher doses of the foods that compose the formulation should be encouraged to investigate whether these foods can positively influence the lipid profiles of these patients.
\end{abstract}

Keywords: HIV/AIDS serodiagnosis. AIDS. Dyslipidemia. Hyperuricemia.

\section{INTRODUCTION}

Acquired immunodeficiency syndrome (AIDS) has emerged as a serious public health problem worldwide. From 1981 to June 2011, there were 608,230 cases of AIDS registered in Brazil ${ }^{1,2}$.

The first antiretroviral drug active against human immunodeficiency virus (HIV) was licensed in 1987, though the initial enthusiasm turned into disappointment with its use as a monotherapy. In contrast, highly active antiretroviral therapy (HAART), which produces a significant attenuation of the viral load, has resulted in important and positive changes in the national public health system with regard to AIDS. In

Address to: Dra Rosângela dos Santos Ferreira. PPG em Saúde e Desenvolvimento na Região Centro-Oeste/UFMS. Rua Hélio Pereira Coelho 386, Carandá Bosque, 79032-510 Campo Grande, MS, Brasil.

Phone: 5567 9983-0961

e-mail: rosangela.ferreira@ufms.br

Received 30 April 2013

Accepted 4 December 2013 addition, new challenges have arisen with the increased number of people living with AIDS, and new nutritional changes have emerged in this patient population, particularly metabolic changes characterized by hyperglycemia, dyslipidemia, and lipodystrophy ${ }^{3}$, emphasizing the relationship between nutrition and AIDS.

The nutritional approach plays a critical role in the treatment of HIV/AIDS patients. Indeed, a healthy diet increases the levels of cluster of differentiation 4+ (CD4+) lymphocytes, enhances intestinal absorption, and reduces complications caused by diarrhea, muscle loss, lipodystrophy, and any other symptoms that, in one way or another, may be reversed or minimized by a balanced $\operatorname{diet}^{4}$.

Foods such as oat bran, soy protein, and flaxseeds improve the lipid profile in hypercholesterolemic individuals and, according to the study performed by Harland, have an additive effect when they are used in combination ${ }^{5}$.

Thus, a diet compound was formulated from these foods with the purpose of helping HIV/AIDS patients control the lipid disorders that result from HAART. 
Oats are composed of beta-glucans, which are polysaccharides that form part of the soluble portion of dietary fiber and affect serum cholesterol levels and low-density lipoprotein (LDL) $)^{6-8}$, especially in hypercholesterolemic individuals9.

Soy consumption can reduce the risk of metabolic syndrome because of such components as soluble fiber, complex carbohydrates, oligosaccharides, vitamins, minerals, and phytoestrogens, particularly the isoflavones genistein, daidzein, and glycitein ${ }^{10,11}$.

Flaxseed is one of the richest sources of alpha-linolenic acid and lignans, both of which can reduce total cholesterol and LDLcholesterol ${ }^{12-15}$. In addition to their cholesterol-lowering effect, flaxseed ${ }^{16,18}$ and oat ${ }^{19}$ have been reported to cause a regression of the atherosclerosis process in animals.

The present study investigated whether such a formulation would influence the lipid profile of HAART-treated AIDS patients with dyslipidemia, without causing uricemia, as compounds containing soy and grains typically have hyperuricemic effects.

\section{METHODS}

The present study represents part of the doctoral thesis research of Rosangela dos Santos Ferreira for the Midwest Region Health and Development Graduate Program (Programa de Pós-Graduação de Saúde e Desenvolvimento na Região Centro-Oeste) of the Federal University of Mato Grosso do Sul (Universidade Federal de Mato Grosso do Sul).

The AIDS patients who participated in this research underwent their follow-up appointments at the outpatient clinics of the Specialty Center for Infectious and Parasitic Diseases (Centro de Especialidades em Doenças Infecciosas e Parasitárias, CEDIP - Nova Bahia) and the Day Hospital of the University Hospital of the Federal University of Mato Grosso do Sul (Universidade Federal de Mato Grosso do Sul); both centers are located in Campo Grande, State of Mato Grosso do Sul.

All of the patients $(n=139)$ who sought treatment from February 2011 to July 2012 were invited to participate in this study.

However, according to the inclusion criteria, the patients must have been using HAART and presenting with dyslipidemia with or without the use of hypolipidemic medications. Patients with renal failure, pregnant women, and indigenous patients who recently initiated, switched, or stopped the use of HAART or lipid-lowering medications were excluded from this study. A total of 89 patients were included in this research.

Furthermore, the patients who did not regularly use the diet compound and patients who ceased follow-up prior to completing 3 months of monitoring were excluded, resulting in a total sample population of 31 participants.

During the first contact, an informed consent form was signed by each patient after a detailed explanation of the research.

A consultation was then performed to provide nutritional guidance for a low-fat and low-cholesterol diet, and an interview was conducted.
The interview included a structured questionnaire that addressed sociodemographic characteristics, anthropometric measurements (waist-hip ratio, waist circumference, and body mass index (BMI)), and laboratory tests examining total cholesterol, high-density lipoprotein (HDL)-cholesterol, lowdensity lipoprotein (LDL)-cholesterol, triglycerides, and uric acid levels. The data collection was performed before and after 3 months of consumption of the formulation.

The compound was prepared with 1 part flaxseed, 1 part textured soy protein, and 2 parts oat bran, such that $40 \mathrm{~g}$ (the recommended daily intake for each patient) contained approximately $10 \mathrm{~g}$ of ground flaxseed, $10 \mathrm{~g}$ of textured soy protein, and $20 \mathrm{~g}$ of oat bran. The components were weighed and mixed to homogenize the compound, and the compound was bottled and labeled for distribution.

Each patient received 3 packets containing 1,200g of the compound and was instructed to consume $40 \mathrm{~g}$ of the product per day using a home measure as a reference. The patients were instructed to consume the product in milk preparations, such as vitamins drinks, porridge, and yogurt, or by adding the compound cooked or uncooked to fruits, soups, and beans in their lunch or dinner meals.

The study evaluated the patients before and after 3 months of consumption, constituting an uncontrolled before and after study.

The variables of total cholesterol, HDL-cholesterol, LDLcholesterol, triglycerides, and uricemia were summarized and represented by the relevant descriptive statistics, including the absolute and relative number, mean, and standard deviation. To compare the laboratory levels before and after the intervention, a $t$ test was used for paired samples, and the Wilcoxon test was used between the 2 groups; a $t$ test was used for independent samples, whereas the Mann-Whitney test was used for 3 groups. An Analysis of Variance or the Kruskal-Wallis test was used after checking the normality of the distribution at a 5\% significance level (p-values for two-tailed). The BioEstat version 5.0 program was used.

\section{Ethical considerations}

The present study was approved by the Ethics Committee on Human Research of the Federal University of Mato Grosso do Sul (Universidade Federal de Mato Grosso do Sul), No. 1630 of $10 / 20 / 2009$.

\section{RESULTS}

Of the 31 patients, $15(48.4 \%)$ were female, and $16(51.6 \%)$ were male. The patients' ages ranged from 31 to 81 years, with an average age of 50.35 years.

Six (19.4\%) patients were followed up with at the outpatient clinic of the Day Hospital/University Hospital-Federal University of Mato Grosso do Sul (HU-UFMS), and 25 (80.7\%) patients were followed at CEDIP - Nova Bahia.

When analyzing the results, only the levels of total cholesterol decreased after consuming the formulation for 3 months. The total cholesterol levels decreased from $204.3 \mathrm{mg} / \mathrm{dL}$ 
to $200.8 \mathrm{mg} / \mathrm{dL}$ (a $1.7 \%$ decrease), which was not considered to be clinically or statistically significant. The HDL-cholesterol, LDL-cholesterol, and triglyceride levels increased by $4.5 \%, 1 \%$, and $6.2 \%$, respectively, and uricemia increased by $4.3 \%$. The variations in the laboratory results before and after the study were not significant (Table 1).

The female patients exhibited no reduction in any of the parameters studied, whereas the males exhibited decreases in total cholesterol (3.8\%) and in LDL-cholesterol $(0.7 \%)$; however, these changes were not significant.

The male patients presented greater uric acid values compared to the female patients, both before and after the intervention (Table 2).

All the studied patients were being treated with HAART, and $18(58.1 \%)$ were using medications of the protease inhibitor (PI) class; 13 (41.9\%) patients had no PIs in their regimen.

All of the laboratory parameters that were analyzed before the nutritional intervention demonstrated that the patients using PIs exhibited higher values, both for the lipid profile and the uricemia analysis.

In the group without PIs, there was a decrease in all the lipid profile values $(4.5 \%$ for total cholesterol, $2.3 \%$ for HDL-cholesterol, 2.4\% for LDL-cholesterol, and 13.8\% for triglycerides) and an increase in uricemia (7.9\%). Conversely,

TABLE 1 - Mean and standard deviation of the lipid levels of AIDS patients before and after the use of the diet formulation, Campo Grande, State of Mato Grosso do Sul, Brazil, 2012 ( $\mathrm{n}=31)$.

\begin{tabular}{lccc}
\hline Laboratory levels & Mean & $\pm \mathrm{SD}$ & $\mathrm{p}$ \\
\hline Total cholesterol & & & \\
before & 204.3 & 38.8 & $0.537^{*}$ \\
after & 200.8 & 30.1 & \\
\hline
\end{tabular}

\begin{tabular}{lccc}
\hline HDL & & & \\
before & 44.3 & 15.3 & \\
after & 46.3 & 12.8 & $0.456^{* *}$ \\
\hline LDL & & & \\
before & 122.1 & 34.5 & \\
after & 123.3 & 24.7 & $0.836^{*}$ \\
\hline
\end{tabular}

Triglycerides

\begin{tabular}{llll} 
before & 177.0 & 101.1 & \\
after & 188.0 & 146.0 & $0.412^{* *}$ \\
\hline
\end{tabular}

Uric acid

\begin{tabular}{llll} 
before & 4.7 & 1.7 & \\
after & 4.9 & 1.8 & $0.298^{*}$ \\
\hline
\end{tabular}

AIDS: acquired immunodeficiency syndrome; SD: standard deviation; HDL: high-density lipoprotein; LDL: low-density lipoprotein. ${ }^{*} \mathrm{~T}$ test for paired samples. ${ }^{* *}$ Wilcoxon test. in the group using PIs and HAART, all of the study variables increased: total cholesterol by $0.1 \%$, HDL-cholesterol by $6 \%$, LDL-cholesterol by $1.2 \%$, triglycerides by $9.2 \%$, and uric acid by $5.9 \%$. Nonetheless, these variations in the laboratory results before and after the study were not significant (Table 3).

Before the consumption of the compound, the patients using PIs exhibited higher triglyceride and uric acid values than the patients who were not using PIs; however, after consumption, this was observed for the triglyceride and total cholesterol levels (Table 3).

Of the 31 patients, $16(51.6 \%)$ were currently taking lipidlowering medications. There were 4 groups of patients: those who were not using lipid-lowering drugs (48.4\%, 15 patients); patients taking only a statin (rosuvastatin) $(16.1 \%, 5$ patients);

TABLE 2 - Mean and standard deviation of lipid levels of AIDS patients before and after the use of the diet formulation according to gender, Campo Grande, State of Mato Grosso do Sul, Brazil, $2012(n=31)$.

\begin{tabular}{lcccccc}
\hline & \multicolumn{4}{c}{ Gender } \\
\cline { 2 - 3 } & \multicolumn{2}{c}{ male } & & female & \\
\cline { 2 - 3 } Laboratory levels & mean & $\pm \mathrm{SD}$ & & mean $\pm \mathrm{SD}$ & $\mathrm{p}$ \\
\hline $\begin{array}{l}\text { Total cholesterol } \\
\text { before }\end{array}$ & 201.8 & 47.0 & & 206.9 & 29.0 & $0.720^{\mathrm{b}}$ \\
after & 194.1 & 31.3 & & 207.9 & 28.1 & $0.207^{\mathrm{b}}$ \\
$\mathrm{p}$ (before x after) & $0.336^{\mathrm{a}}$ & & $0.904^{\mathrm{a}}$ & \\
\hline
\end{tabular}

HDL

\begin{tabular}{lrrrrr} 
before & 42.1 & 12.0 & 46.5 & 18.4 & $0.432^{\mathrm{b}}$ \\
after & 42.3 & 12.9 & 50.6 & 11.6 & $0.068^{\mathrm{b}}$ \\
$\mathrm{p}$ (before x after) & & $0.973^{\mathrm{a}}$ & \multicolumn{2}{c}{$0.189^{\mathrm{a}}$} \\
\hline
\end{tabular}

LDL

\begin{tabular}{lcrrrr} 
before & 122.0 & 41.9 & 122.2 & 25.2 & $0.986^{\mathrm{b}}$ \\
after & 121.1 & 25.6 & 125.8 & 24.4 & $0.625^{\mathrm{b}}$ \\
$\mathrm{p}$ (before x after) & $0.921^{\mathrm{a}}$ & $0.521^{\mathrm{a}}$ & \\
\hline
\end{tabular}

Triglycerides

\begin{tabular}{lccccc} 
before & 191.6 & 115.2 & 159.0 & 81.2 & $0.174^{\mathrm{d}}$ \\
after & 201.4 & 162.8 & 171.5 & 126.8 & $0.245^{\mathrm{d}}$ \\
p (before x after) & $0.728^{\mathrm{c}}$ & $0.442^{\mathrm{c}}$ & \\
\hline
\end{tabular}

Uric acid

\begin{tabular}{lrrrrr} 
before & 5.5 & 1.3 & 3.8 & 1.5 & $0.003^{\mathrm{b}}$ \\
after & 5.7 & 1.6 & 4.1 & 1.6 & $0.009^{\mathrm{b}}$ \\
p (before x after) & & $0.482^{\mathrm{a}}$ & \multicolumn{4}{c}{$0.456^{\mathrm{a}}$} \\
\hline
\end{tabular}

AIDS: acquired immunodeficiency syndrome; SD: standard deviation; HDL: high-density lipoprotein; LDL: low-density lipoprotein. ${ }^{\mathrm{a}} \mathrm{T}$ test for paired samples; ${ }^{\mathrm{b}} \mathrm{T}$ test for independent samples; ${ }^{\mathrm{c}}$ Wilcoxon test; dMann Whitney Test. 
TABLE 3 - Mean and standard deviation of lipid levels of AIDS patients before and after the use of the diet formulation according to the antiretroviral scheme, Campo Grande, State of Mato Grosso do Sul, Brazil, 2012 ( $\mathrm{n}=31)$.

\begin{tabular}{|c|c|c|c|c|c|}
\hline \multirow[b]{3}{*}{ Laboratory levels } & \multicolumn{4}{|c|}{ HAART } & \multirow[b]{3}{*}{$\mathrm{p}$} \\
\hline & \multicolumn{2}{|c|}{ with PI ( $\mathrm{n}=18)$} & \multicolumn{2}{|c|}{ without PI $(n=13)$} & \\
\hline & mean & $\pm \mathrm{SD}$ & mean & $\pm \mathrm{SD}$ & \\
\hline \multicolumn{6}{|l|}{ Total cholesterol } \\
\hline before & 212.6 & 43.9 & 197.8 & 26.5 & $0.305^{\mathrm{b}}$ \\
\hline after & 212.9 & 29.9 & 188.8 & 23.9 & $0.029^{b}$ \\
\hline $\mathrm{p}$ (before $\mathrm{x}$ after) & \multicolumn{2}{|c|}{$0.979^{\mathrm{a}}$} & \multicolumn{2}{|c|}{$0.233^{\mathrm{a}}$} & \\
\hline
\end{tabular}

HDL

\begin{tabular}{lcrcrc} 
before & 43.6 & 16.1 & 47.1 & 14.3 & $0.232^{\mathrm{d}}$ \\
after & 46.2 & 11.5 & 46.0 & 14.5 & $0.808^{\mathrm{d}}$ \\
p (before x after) & \multicolumn{2}{c}{$0.163^{\mathrm{c}}$} & \multicolumn{4}{c}{$0.724^{\mathrm{c}}$} \\
\hline
\end{tabular}

LDL

\begin{tabular}{lcrrrr} 
before & 125.9 & 42.4 & 119.4 & 23.7 & $0.918^{\mathrm{d}}$ \\
after & 127.4 & 24.6 & 116.5 & 24.9 & $0.272^{\mathrm{b}}$ \\
p (before x after) & $0.638^{\mathrm{c}}$ & \multicolumn{4}{c}{$0.592^{\mathrm{a}}$} \\
\hline
\end{tabular}

Triglycerides

\begin{tabular}{lcrcrc} 
before & 212.3 & 120.5 & 139.6 & 61.0 & $0.009^{\mathrm{d}}$ \\
after & 231.9 & 185.5 & 120.3 & 23.4 & $0.036^{\mathrm{b}}$ \\
p (before x after) & $0.443^{\mathrm{c}}$ & $0.824^{\mathrm{c}}$ \\
\hline
\end{tabular}

Uric acid

\begin{tabular}{|c|c|c|c|c|c|}
\hline before & 5.1 & 1.5 & 3.8 & 1.5 & $0.035^{\mathrm{d}}$ \\
\hline after & 5.4 & 1.8 & 4.1 & 1.5 & $0.101^{\mathrm{d}}$ \\
\hline $\mathrm{p}$ (before $\mathrm{x}$ after) & & & & & \\
\hline
\end{tabular}

AIDS: acquired immunodeficiency syndrome; SD: standard deviation; HAART: highly active antiretroviral therapy; HDL: high-density lipoprotein; LDL: low-density lipoprotein. ${ }^{\mathrm{a}} \mathrm{T}$ test for paired samples; ${ }^{\mathrm{b}} \mathrm{T}$ test for independent samples; ${ }^{\mathrm{c}}$ Wilcoxon test; ${ }^{\mathrm{d}}$ Mann Whitney Test.

patients taking only a fibrate (ciprofibrate) $(12.9 \%, 4$ patients); and patients using a statin and a fibrate (22.6\%, 7 patients).

There was no statistically significant difference in the laboratory results before and after compound consumption in the same group or among the groups (Table 4).

\section{DISCUSSION}

The regular consumption of a formulation containing oat bran, soy protein and flax seed for 3 months together with individualized dietary guidance did not reduce the lipid levels of the patients; however, it did not contribute to an increase in uricemia. The small number of participants and their heterogeneity, either related to the classes of dyslipidemia or to the type of drugs that they were using, may have limited the investigation of the compound's effect by interfering with the detection power of the statistical tests.

However, all of the participants who completed the data collection during the fixed period were included in this study.

Nonetheless, the acceptance of this diet by the individual required a new routine, which resulted in many patients leaving the study during the follow-up months.

The follow-up time is an important point to be considered due to the behavioral component of the dietary intervention and the variability between a change in the food consumption level and its impact on metabolic outcomes ${ }^{20}$.

Borodin et al. ${ }^{21}$ showed that the duration of interventions must be increased to affect lipid profiles in the general population; indeed, it was observed that the introduction of soy protein for 1 month did not reduce lipid parameters, though it did have a significant effect after 2 months.

The components of the formulation used in this study were flaxseed, soy protein, and oat bran. Triturated flax was used because it allows for the absorption of alpha-linolenic acid ${ }^{22}$, a major contributor to the hypolipidemic effect ${ }^{14,23}$; furthermore, the antioxidants present in flaxseed act synergistically to enhance the prevention of inflammatory disorders and heart disease $^{24}$. Molena-Fernandes ${ }^{25}$ showed that the consumption of $10 \mathrm{~g}$ flaxseed and/or $20 \mathrm{~g}$ per capita of linseed resulted in the rapid elimination of cholesterol, and Couto $^{26}$ found a significant reduction in the basal and final serum triglyceride levels (81.8\%) of 2 groups of monitored patients who consumed $10 \mathrm{~g}$ and $20 \mathrm{~g}$ per capita of triturated flaxseed.

Studies on soy isoflavones have revealed a statistically significant reduction in serum cholesterol levels due to increased LDL receptor activity ${ }^{27,28}$.

Oat bran has a higher concentration of beta-glucans than other forms of oats ${ }^{29}$, resulting in improved lipid profiles and beneficial effects on risk factors for heart disease through multiple mechanisms ${ }^{30-32}$, including immunomodulation and the formation of viscous solutions in the intestine ${ }^{29}$.

However, in our study, there were no statistically significant differences in the levels of total cholesterol, HDL, LDL, triglycerides, or uric acid after the 3 months of consumption of the formulation.

The gender analysis indicated no reduction in lipids after consumption, and, despite the higher uric acid content in the male patients compared to the female patients, there was no increase in the uric acid values before and after the intervention. It has been observed that higher uric acid levels in women is a risk factor for heart disease ${ }^{33}$.

Before the consumption of the compound, the patients using PIs had higher triglyceride and uric acid values than the patients not using PIs, and this was observed for triglycerides and total cholesterol following the intervention. However, within the same group, there was neither a reduction in lipids nor an increase in uric acid after the intervention. 
TABLE 4 - Mean and standard deviation of lipid levels of AIDS patients before and after the use of the diet formulation according to the use of hypolipidemic agents, Campo Grande, State of Mato Grosso do Sul, Brazil, 2012 ( $\mathrm{n}=31)$.

\begin{tabular}{|c|c|c|c|c|c|c|c|c|c|}
\hline \multirow[b]{4}{*}{ Laboratory levels } & \multicolumn{8}{|c|}{ Hypolipidemic agent } & \multirow[b]{4}{*}{$\mathrm{p}$} \\
\hline & \multirow{2}{*}{\multicolumn{2}{|c|}{$\begin{array}{l}\text { none } \\
(\mathrm{n}=15)\end{array}$}} & \multirow{2}{*}{\multicolumn{2}{|c|}{$\begin{array}{l}\text { statin } \\
(\mathrm{n}=5)\end{array}$}} & \multirow{2}{*}{\multicolumn{2}{|c|}{$\begin{array}{l}\text { fibrate } \\
(n=4)\end{array}$}} & \multirow{2}{*}{\multicolumn{2}{|c|}{$\begin{array}{c}\text { statin + fibrate } \\
\quad(n=7)\end{array}$}} & \\
\hline & & & & & & & & & \\
\hline & mean & $\pm \mathrm{SD}$ & mean & $\pm \mathrm{SD}$ & mean & $\pm \mathrm{SD}$ & mean & $\pm \mathrm{SD}$ & \\
\hline \multicolumn{10}{|l|}{ Total cholesterol } \\
\hline after & 206.6 & 24.1 & 191.0 & 35.6 & 200.0 & 47.5 & 198.7 & 33.2 & $0.807^{b}$ \\
\hline $\mathrm{p}$ (before $\mathrm{x}$ after) & \multicolumn{2}{|c|}{$0.540^{\mathrm{a}}$} & \multicolumn{2}{|c|}{$0.271^{\mathrm{a}}$} & \multicolumn{2}{|c|}{$0.899^{\mathrm{a}}$} & \multicolumn{2}{|c|}{$0.378^{\mathrm{a}}$} & \\
\hline \multicolumn{10}{|l|}{ HDL } \\
\hline before & 44.8 & 15.7 & 46.2 & 21.9 & 46.3 & 7.3 & 40.6 & 16.4 & $0.916^{\mathrm{b}}$ \\
\hline before & 128.8 & 27.0 & 125.4 & 58.6 & 116.7 & 28.4 & 103.7 & 31.1 & $0.547^{b}$ \\
\hline after & 128.6 & 23.8 & 113.2 & 37.8 & 116.0 & 20.4 & 125.0 & 20.1 & $0.673^{b}$ \\
\hline $\mathrm{p}$ (before $\mathrm{x}$ after) & \multicolumn{2}{|c|}{$0.976^{\mathrm{a}}$} & \multicolumn{2}{|c|}{$0.352^{\mathrm{a}}$} & \multicolumn{2}{|c|}{$0.964^{\mathrm{a}}$} & \multicolumn{2}{|c|}{$0.179^{\mathrm{a}}$} & \\
\hline \multicolumn{10}{|l|}{ Triglycerides } \\
\hline before & 161.8 & 73.2 & 134.3 & 39.4 & 186.5 & 83.5 & 235.4 & 160.9 & $0.365^{\mathrm{d}}$ \\
\hline after & 160.5 & 101.7 & 171.8 & 72.4 & 202.3 & 145.2 & 240.6 & 245.8 & $0.938^{\mathrm{d}}$ \\
\hline p (before $\mathrm{x}$ after) & \multicolumn{2}{|c|}{$0.972^{\mathrm{c}}$} & \multicolumn{2}{|c|}{$0.343^{\mathrm{a}}$} & \multicolumn{2}{|c|}{$0.665^{\mathrm{a}}$} & \multicolumn{2}{|c|}{$1.000^{\mathrm{c}}$} & \\
\hline
\end{tabular}

AIDS: acquired immunodeficiency syndrome; SD: standard deviation; HDL: high-density lipoprotein; LDL: low-density lipoprotein. ${ }^{\mathrm{a}} \mathrm{T}$ test for paired samples; ${ }^{\mathrm{b}}$ ANOVA (analysis of variance); ${ }^{\mathrm{c}}$ Wilcoxon Test; ${ }^{\mathrm{d}}$ Kruskal Wallis Test.

These data are in agreement with studies that demonstrate that lipid abnormalities are more evident among HIV-infected patients after the introduction of HAART ${ }^{34-37}$, and significantly higher increases in lipids were observed when PIs were added to the antiretroviral scheme ${ }^{38,39}$.

Therefore, it was observed that the compound employed did not provoke a significant change in the lipid profile of the study population during 3 months of dietary intervention.

Although there was no difference in the observed lipid values after the intervention when the results were stratified according to the use of hypolipidemic drugs, it is possible be that the sample size was not large enough to establish differences between the hypolipidemic agents.

The present study demonstrated that there were minor and insignificant variations in uricemia following the use of the formulation. The compound used contained soybeans in the form of textured protein, which is the most concentrated form of the food $^{40}$; however, soybeans are commonly implicated in high uric acid levels ${ }^{41-43}$. Nonetheless, Messina and $\mathrm{Chan}^{44}$ conducted a review of soy foods and hyperuricemia and found no evidence of increased uricemia related to soy intake.

The regular consumption (for 3 months) of a feed compound containing oat bran, textured soy protein, and triturated ground flaxseed together with the individualized dietary guidance did not reduce lipid levels; however, the compound did not contribute to increased uricemia in the study group.

When the results were stratified according to the antiretroviral scheme of the patients, those using PIs showed higher triglyceride and total cholesterol values after the consumption of the compound compared to those who did not use PIs.

This occurrence is most likely due to the strong impact of PIs on the lipid metabolism of these patients. 
Further studies with a larger number of participants and higher doses of the components of the compound should be encouraged, particularly addressing patients who are being treated with HAART therapeutic schemes, to investigate whether the compound can positively influence the lipid profile of these patients.

\section{CONFLICT OF INTEREST}

The authors declare that there is no conflict of interest.

\section{FINANCIAL SUPPORT}

This study was financed by funds from the Department of Science and Technology of the Secretariat of Science, Technology, and Strategic Resources of the State of Mato Grosso do Sul (Departamento de Ciência e Técnologia da Secretaria da Ciência, Tecnologia e Insumos Estratégicos do Mato Grosso do Sul - Decit/SCTIE/MS) and the Treasury of the State of Mato Grosso do Sul, available via FUNDECT (Foundation to Support the Development of Education, Science and Technology of the State of Mato Grosso do Sul/Fundação de Apoio ao Desenvolvimento do Ensino, Ciência e Tecnologia do Estado de Mato Grosso do Sul) by public notice no. 07/2009/ $\mathrm{MS} / \mathrm{CNPq} / \mathrm{SES}$.

\section{REFERENCES}

1. Ministério da Saúde. Departamento de DST, AIDS e Hepatites Virais. AIDS no Brasil [Internet]. Brasília: Ministério da Saúde; 2011. Available at: http://www.aids.gov.br/pagina/aids-no-brasil.

2. Ministério da Saúde. Departamento de DST, AIDS e Hepatites Virais. Boletim epidemiológico AIDS e DST 2011 [Internet]. Brasília: Ministério da Saúde; 2011. Available at http://www.aids.gov.br/publicacao/2011/ boletim_epidemiologico_2011.

3. Valente AMM, Reis AF, Machado DM, Succi RCM, Chacra AR. Alterações metabólicas da síndrome lipodistrófica do HIV. Arq Bras Endocrinol Metab 2005; 49:871-881.

4. Ministério da Saúde. Programa Nacional de DST e AIDS. Manual clínico de alimentação e nutrição na assistência a adultos infectados pelo HIV. Brasília: Ministério da Saúde; 2006.

5. Harland JI. Food combinations for cholesterol lowering. Nutr Res Rev 2012; 25:249-266.

6. Brown L, Rosner B, Willett WW, Sackss FM. Cholesterol-lowering effects of dietary fiber: a meta-analysis. Am J Clin Nutr 1999; 69:30-42.

7. Haggard L, Andersson M, Punga AR. $\beta$-glucans reduce LDL cholesterol in patients with myasthenia gravis. Eur J Clin Nutr 2013; 67:226-227.

8. Wolever TM, Gibbs AL, Brand-Miller J, Duncan AM, Hart V, Lamarche B, et al. Bioactive oat $\beta$-glucan reduces LDL cholesterol in Caucasians and non-Caucasians. Nutr J 2011; 10:130.

9. Queenan KM, Stewar ML, Smith KN, Thomas W, Fulcher RG, Slavin JL. Concentrated oat B-glucan, a fermentable fiber, lowers serum cholesterol in hypercholesterolemic adults in a randomized controlled trial. Nutr $\mathbf{J}$ 2007; 6:6.

10. Jenkins DA, Kendall CW, Jackson CJ, Connely PW, Parker T, Faulkner D, et al. Effects of high- and low-isoflavonesoyfoods on blood lipids, oxidized LDL, homocysteine, and blood pressure in hyperlipidemic men and women. Am J Clin Nutr 2002; 76:365-372.
11. Torres NT, Tovar-Palacio AR. La historia del uso de lasoyaen México, su valor nutricional y suefectoenlasalud. Salud Publica Mex 2009; 51:246-254.

12. Fukumitsu S, Villareal MO, Onaga S, Aida K, Han J, Isoda H. $\alpha$-Linolenic acid suppresses cholesterol and triacylglycerol biosynthesis pathway by suppressing SREBP-2, SREBP-1a and -1c expression. Cytotechnology 2012; Special Issue. Available at: http://link.springer.com/article/10.1007/ s10616-012-9510-x

13. Khalatbari Soltani S, Jamaluddin R, Tabibi H, Mohd Yusof BN, Atabak S, Loh SP, et al. . Effects of flaxseed consumption on systemic inflammation and serum lipid profile in hemodialysis patients with lipid abnormalities. Int Hemodial 2013; 17:275-281

14. Brant LH, Cardozo LF, Velarde LG, Boaventura GT. Impact of flaxseed intake upon metabolic syndrome indicators in female Wistar rats. Acta Cir Bras 2012; 27:537-543.

15. Fukumitsu S, Aida K, Shimizu H, Toyoda K. Flaxseed lignan lowers blood cholesterol and decreases liver disease risk factors in moderately hypercholesterolemic men. Nutr Res 2010; 30:441-446.

16. Lucas EA, Lightfoot SA, Hammond LJ, Devareddy L, Khalil DA, Daggy BP, et al. Flaxseed reduces plasma cholesterol and atherosclerotic lesion formation in ovariectomized Golden Syrian hamsters. Atherosclerosis 2004; 173:223-229.

17. Prasad K. Regression of hypercholesterolemic atherosclerosis in rabbits by ecoisolariciresinoldiglucoside isolated from flaxseed. Atherosclerosis $2008 ; 197: 34-42$

18. Francis AA, Deniset JF, Áustria JA, Lavallee RK, Maddaford GG, Hedley TE, et al. . Effects of dietary flaxseed on atherosclerotic plaque regression. Am J Physiol Heart Circ Physiol 2013; 304:H1743-1751

19. Andersson KE, Hellstrand P. Dietary oats and modulation of atherogenic pathways. Mol Nutr Food Res 2012; 56:1003-1013.

20. Almeida LB, Giudici KV, Jaime PC. Consumo alimentar e dislipidemia decorrente da terapia antirretroviral combinada para infecção pelo HIV: uma revisão sistemática. Arq Bras Endocrinol Metab 2009; 53 : 519-527.

21. Borodin EA, Menshikova IG, Dorovskikh VA, Feokitstova NA, Shtarberg MA, Yamamoto T, et al. Effects of two-month consumption of $30 \mathrm{~g}$ a day of soy protein isolate or skimmed curd protein on blood lipid concentration in Russian adults with hyperlipidemia. J Nutr Sci Vitaminol 2009; 55: 492-497.

22. Austria JA, Richard MN, Chahine MN, Edel AL, Malcolmson LJ, Dupasquier CM, et al. Bioavailability of alpha-linolenic acid in subjects after ingestion of three diferente forms of flaxseed. J Am Coll Nutr 2008; 27:214-221.

23. Rodriguez-Leyva D, Basset CMC, McCullough R, Pierce GN. The cardiovascular effects of flaxseed and its omega-3 fatty acid, alphalinolenic acid. Can J Cardiol 2010; 26:489-496.

24. Govington MB. Omega-3 fatty acids. Am Fam Phys 2004; 70:133-140.

25. Molena-Fernandes CA. Avaliação dos efeitos da suplementação com farinha de linhaça (Linum usitatissimum L.) marrom e dourada sobre o perfil lipídico e a evolução ponderal em ratos Wistar. Rev Bras Pl Med 2010; 1:201-207.

26. Couto NA, Wichmann FMA. Efeitos da farinha da linhaça no perfil lipídico e antropométrico de mulheres. Alim Nutr 2011; 22:601-608.

27. Kirk EA, Shuterland P, Wang SA. Dietary isoflavones reduce plasma cholesterol and atherosclerosis in C57BL/6 mice, but not LDL receptordeficient mice. Journal of Nutrition, Bethesda 1998; 128:954-959.

28. Prediger CCC, Olinto MTA, Nácul LC, Ziegler DR, Pattussi MP. Efeitos do consumo de proteína de soja contendo isoflavonas sobre a concentração de lipídeos séricos em mulheres: metanálise. Rev Nutr [online] 2011; 24:161-172.

29. El Khoury D, Cuda C, Luhovyy BL, Anderson GH. Beta Glucan: Health Benefits in Obesity and Metabolic Syndrome. J Nutr Metab 2012; 2012: 28 pages. Article ID 851362. 
30. Dikeman CL, Murphy MR, Fahey Jr GC. Dietary fibers affect viscosity of solutions and simulated human gastric and small intestinal digest. J Nutr 2006; 136:913-919.

31. Rogovik A, Jenkins A, Breitman P, Vuksan V. A blend of highly viscous polysaccharide decreases relative CVD risk in healthy individuals and those with diabetes and metabolic syndrome. FASEB J 2006; 20:A578.

32. Gonçalves MCR, Costa MJC, Asciutti LSR, Diniz MFFM. Fibras dietéticas solúveis e suas funções nas dislipidemias Rev Bras Nutr Clin 2007; 22:167-173.

33. Rodrigues SL, Baldo MP, Capingana DP, Magalhães P, Dantas EM, Molina MCB, et al. Gender Distribution of Serum Uric Acid and Cardiovascular Risk Factors: Population Based Study. Arq Bras Cardiol 2012; 98:13-21.

34. Sociedade Brasileira de Cardiologia. Departamento de Aterosclerose. IV Diretriz Brasileira Sobre Dislipidemias e Prevenção da Aterosclerose. Vol. 88. São Paulo: Sociedade Brasileira de Cardiologia; 2007.

35. Almeida SEM, Borges M, Fiegenbaun M, Nunes CC, Rossetti MLR. Metabolic changes associated with antirretroviral therapy in HIV-positive patients. Rev Saude Publica 2009; 43:283-290.

36. Silva EFR, Bassichetto KC, Lewi DS. Perfil lipídico, fatores de risco cardiovascular e síndrome metabólica em um grupo de pacientes com AIDS. Arq Bras Cardiol 2009; 93:113-118.
37. Kramer AS, Lazzarotto AR, Sprinz E, Manfori WC. Alterações metabólicas, terapia antiretroviral e doença cardiovascular em idosos portadores de HIV. Arq Bras Cardiol 2009; 93:561-568.

38. Farhi L, Lima DB, Cunha AB. Dislipidemia em pacientes HIV/AIDS em uso de anti-retrovirais num hospital universitário, Rio de Janeiro, Brasil. J Bras Patol Med Lab 2008; 44:175-184.

39. Domingos H. Efeitos metabólicos associados à terapia antirretroviral potente em pacientes com AIDS [dissertação de mestrado]. Campo Grande: Universidade Federal de Mato Grosso do Sul; 2006. 87p.

40. Berno LI, Guimarães-Lopes TG, Cannitti-Brazaca SG. Avaliação da composição centesimal, digestibilidade e atividade inibitória de tripsina em produtos derivados de soja (Glycinemax). Alim Nutr 2007; 18:277-282.

41. Peixoto MRG, Monego ET, Jardim PCV, Carvalho MM, Sousa ALL, Oliveira JS, et al. Dieta e medicamentos no tratamento da hiperuricemia em pacientes hipertensos.Arq Bras Cardiol 2001; 76:463-467.

42. Portero-Mclellan KC, Bernardi JLD, Barbalho SM. Abordagem metabólica e dietética na hiperuricemia e na gota. Rev Bras Nutr Clin 2009; 24:29-32.

43. Roddy E. Hyperuricemia, gout, and lifestyle factors. J Rheumatol 2008; 35:1689-1691.

44. Messina M, Messina VL, Chan P. Soyfoods, hyperuricemia and gout: a review of the epidemiologic and clinical data. Asia Pac J Clin Nutr 2011; 20:347-358. 